\title{
Head Teachers' Administrative Skills and Curriculum Management in Universal Secondary Education Schools in Kiruhura District, Uganda
}

\author{
Florah Kyayemagye ${ }^{1}$, Denis Kintu ${ }^{2, *}$ \\ ${ }^{1}$ Faculty of Education, Department of Education Foundations, Distance \& Lifelong Learning-Bishop Stuart University, Mbarara, Uganda \\ ${ }^{2}$ Faculty of Education, Department of Science Education, Bishop Stuart University, Mbarara, Uganda
}

Email address:

dkintu@educ.bsu.ac.ug (D. Kintu)

${ }^{*}$ Corresponding author

To cite this article:

Florah Kyayemagye, Denis Kintu. Head Teachers' Administrative Skills and Curriculum Management in Universal Secondary Education Schools in Kiruhura District, Uganda. Teacher Education and Curriculum Studies. Vol. 5, No. 3, 2020, pp. 81-93.

doi: $10.11648 /$ j.tecs.20200503.16

Received: March 9, 2020; Accepted: July 7, 2020; Published: July 17, 2020

\begin{abstract}
The study investigated head teachers' administrative skills and curriculum management in Universal Secondary Education (USE) Schools in Kiruhura District of Uganda. The objectives were to identify the head teachers' administrative skills in managing curriculum, to establish the challenges faced by USE school head teachers in curriculum management, and to find the relationship between head teachers' administrative skills and curriculum management. The study employed a cross sectional survey research design. Data was collected using a questionnaire and interview guides administered to head teachers of USE schools and respondents from the Kiruhura district education officer's office. Microsoft office excel and word were used to generate frequencies and tables for easy interpretation and presentation of the data. The research findings revealed that the highest administrative skills used by head teachers in USE schools was involving teachers in curriculum activities which was rated at $90 \%$ by the respondents, whereas absenteeism at $26.8 \%$ for both teachers and students was the biggest challenge faced by secondary schools head teachers. Finally, the respondents indicated that there was a relationship between administrative skills and curriculum, rated at $91 \%$ yes response. The study recommends that stake holders establish monthly workshops aimed at improving head teachers administrative skills in order to attain an improved curriculum management in USE schools.
\end{abstract}

Keywords: Head Teachers' Administrative Skills, Curriculum Management, Universal Secondary Education (USE) Schools

\section{Introduction}

\subsection{Background to the Study}

World over, the purpose of curriculum management is to ensure that all students get the most out of their education. For curriculum to be meaningful, the learners should derive from it, the right behavior, actions, attitudes, skills, knowledge and values. In India, [1] demonstrated that a strong correlation exists between curriculum management at schools and head teacher's leadership styles. The study revealed that it is essential for principals and head teachers to be knowledgeable on new school curriculum and also be skilled in making the best decisions in case of problems.
There are several key concepts that underpin this study. The term and application of administrative skills often go hand in hand with leadership styles. However, the two are related but different in nature. Administrative skills refer to the skills needed to become an administrator. These skills are not limited to filing, organizing, planning, scheduling, coordinating and even staffing.

A leadership style is a leader's way of providing direction, implementing plans, and motivating people. Among the many leadership styles are authoritarian, paternalistic, democratic, laissez-faire, transactional and transformational [2].

The authoritarian leadership style or autocratic leader is where leaders keep close control over followers and direct supervision for fear of followers being unproductive. The 
democratic leadership style consists of the leader sharing the decision-making abilities with group members by promoting the interests of the group members and by practicing social equality through discussion, debate and sharing of ideas and encouragement of people to feel good about their involvement. For the laissez-faire all the rights and power to make decisions is fully given to the worker. This style is sometimes described as a "hands off" leadership style because the leader delegates the tasks to their followers while providing little or no direction to the followers. When it comes to transactional leaders focus is on increasing the efficiency of established routines and procedures. They are more concerned with following existing rules than with making changes to the organization.

Finally, a transformational leader is a type of person in which the leader is not limited by his or her followers' perception. The main objective is to work to change or transform his or her followers' needs and redirect their thinking. It is therefore important for school principals and head teachers to become instructional and curriculum specialists to ease implementation and achieve better results [1].

Several researchers in the United Kingdom have focused on the idea that leadership is one of the most important aspects in determining whether an educational institution is successful or not [3]. However, some countries such as Saudi Arabia have a lack of theoretical and experiential literature. The reason for this could be that the Saudi educational context has failed to focus adequately on preparing head teachers, and the Ministry of Education in Saudi Arabia has not placed enough emphasis on the head teacher's role [4].

Various studies have shown that Secondary Education is in demand and valued in Uganda, and that the government of Uganda has given consideration to policy reform in this sector $[5,6]$. Educational indicators illustrate this change in demand for secondary education in recent years. In 2004, 54\% of students completed primary education; from 1991 to 2004, the gross enrollment rate at the secondary level has increased from $11 \%$ to $19 \%$; net enrollment has had a similar increase from $8 \%$ (1999) to $15 \%$ in 2004 . Private secondary schools have also expanded in the past decade-there are currently 627 privately owned secondary schools compared to 847 that are government-aided, often with little support or training of head teachers and teachers. At the same time, secondary education, while officially decentralized, has not been fully decentralized in practice [7].

Teacher and head teacher deployment, student placement, and testing all remain centralized. The governments of Uganda and donor agencies clearly acknowledge the need to address both access and quality in secondary schools [6]. In a strategic political move, Ugandan president Museveni campaigned for re-election, and won in 2006, on a platform of universal secondary education, the first country in sub-Saharan African to undertake such an educational effort.

Many questions remain for the Ugandan government to address, including to whom they should target training when resources are limited; and which skills are most needed at this time and in the future, as schools change in response to USE. Moreover, across many countries in sub-Saharan Africa including Uganda, head teachers are not adequately prepared for their roles, and few professional development opportunities exist to provide them with the skills they need [8].

The study therefore addressed the questions by assessing head teachers' efficacy in leadership, management, instruction, and community relations basing on the above background. It assessed the head teachers' administrative skills in curriculum management in Uganda looking at Kiruhura District as microcosm of a macro scenario.

\subsection{Problem Statement}

In sub-Saharan Africa, USE school head teachers have little opportunity for advanced education and training. Yet, such training is important because it assists them in improving their roles and responsibilities. Commenting on the same loophole, [9] observe that few educational programs exist in sub-Saharan Africa for the training and development of USE schools head teachers.

Unlike the head teachers in private and non-USE secondary schools where by the head teachers are monitored and guided by the school directors and founders [6], a head teacher under USE, is a single administrative officer in charge of all operations. In addition to the administrative responsibilities that include filing, organizing, planning, scheduling, coordinating and even staffing, the head teacher must teach although with lower number of lessons compared to other teachers [10]. The head teacher therefore is expected to provide expert leadership in all areas of the school programmes to ensure curriculum management [11].

The available records from Uganda National Examinations Board (UNEB) and school files indicate poor performance of secondary schools at both Uganda Certificate of Education (UCE) and in Uganda Advanced Certificate of Education (UACE) in Kiruhura district, as compared to national performance [12].

Despite the lack of available training for head teachers, policy makers recognize the need for policies and practices that improve school management, and this is particularly true in Uganda While the need to improve head teachers' competencies to manage the dynamically changing secondary schools in Uganda exists, policymakers like the Ministry of Education and Sports, are not clear on which skills are most needed and how to best provide effective training for those skills [10].

The study was aimed at assessing Ugandan head teachers' perceived need for knowledge and skills and to develop a training program to address these needs taking Kiruhura district as a case study. It was guided by the following research questions:

i. What administrative skills do head teachers employ in managing curriculum in USE schools in Kiruhura District?

ii. What are the challenges faced by secondary school head teachers while implementing school curriculum in USE 
schools in Kiruhura District?

iii. Is there a relationship between head teachers' administrative skills and curriculum management in USE schools in Kiruhura District?

\subsection{Theoretical Frame Work}

The study was based on Taylor's scientific management theory which advocates for training of staff for better performance [13]. This theory states that a leader's behavior is contingent to the satisfaction, motivation and performance of his or her subordinates. It further postulates that the leader engages in behaviors that compliment subordinates abilities and compensate for deficiencies.

This theory can be classified both as a contingency and as a transactional leadership theory. It is to do with the leader "clearing" the path for the followers to take. It was developed to describe the way the leaders encourage and support their followers in achieving the goals they have been set by making path that they should take clear and easy. In particular, according to this theory leaders should, Clarify the path so subordinates know which way to go, remove road blocks that are stopping them going there and increase the rewards along the route as leaders can take a strong or limited approach.

This theory explains that performance of head teachers' instructional supervision practices depend upon effort. Instructional supervision of head teachers influence teachers' commitments in teaching, improved teaching and learning techniques, and improved academic performance. Head teachers can motivate teachers for academic performance. According to this theory, leaders who show the way and help followers along a path are effective in leading them. This approach assumes that there is one right way of achieving a goal and the leader can see but the followers cannot.

However, in adopting the path goal theory for this study, the researcher is aware of its shortcomings. The role of other stakeholders in the schools, their creativity and innovations should be encouraged and nurtured. Team work and delegation of responsibilities should be encouraged. This theory casts the leader who is the head teacher for this study, as the "knowing person" and the followers as "dependants". However, it assumes that the followers are completely rational and that appropriate methods can be deterministically selected depending on the situation.

\section{Literature Review}

\subsection{Curriculum Management Activities}

Curriculum as field of study is seen by many as largely being concerned with the mechanics of curriculum planning, development and innovation.

According to [14] its existence came in the 20th century and it emerged out of the need to explore educational problems in their own right, without dominant monopoly from any of the contributing disciplines such as philosophy, psychological and sociology.
In sub-Saharan Africa where Uganda and Kiruhura district lies, USE school head teachers have little opportunity for advanced education and training. Yet, such training is important because it assists them in improving their roles and responsibilities. Commenting on the same loophole, [9] observe that few educational programs exist in sub-Saharan Africa for the training and development of USE schools head teachers. This same view is repeated by [14].

While the need to improve head teachers' competencies to manage the dynamically changing secondary schools in Uganda exists, policymakers like the Ministry of Education and Sports, are not clear on which skills are most needed and how to best provide effective training for those skills [10].

The study was aimed at assessing head teachers' administrative skills and curriculum management of USE Schools in Kiruhura District, it focused on Ugandan head teachers' perceived need for knowledge and skills and to develop a training program to manage the school curriculum. One of the rationales for targeting head teacher training, like other strategies to improve educational quality, is that it can potentially have a greater impact and make the most efficient use of resources [15].

According to Alkarni \& Brian, a curriculum is just a big learning plan. The activities that make up curriculum management include curriculum mapping, content, structure and sequence analysis. It also involves student assessment, program evaluation, research, review, and finally one needs to take the data gathered, and decide whether or not curriculum changes are needed [4]. Further, the Ministry of Education and Sports encourages schools heads to critically impart assessment documents in their schools in order to catch up with the curriculum system [16].

Skills of head teachers differ from country to country, depending on the policy of that particular nation. [17], say that globally, the majority of school leaders were not trained as school administrators but they assume offices because of their experience. Nevertheless, in some countries like United Kingdom and Switzerland, future and serving head teachers are trained in management of schools. Also, according to [17], in other countries such as Slovenia, Estovenia and Catelonia, Northern Ireland, Hungary and Lithuania, specific leadership training and or certification is required before one assumes headship roles.

The lack of specific leadership training and requirements other than experience seems to suggest that intuitive leading prevails in the majority of countries [17].

In Uganda, the Ministry of Education and Sports set a standard whereby, every head teacher in government secondary school must be a degree holder [18]. However, according to [19], government occasionally organize induction courses for the newly appointed head teachers, and refresher courses for serving head teachers, but he said $20 \%$ hardly received any induction in management training.

The research carried out in USA about the effect of the quality of teacher on school performance, results revealed that teacher quality is the most important variable in determining students' achievement [9]. 
In the researchers' view, teachers' performance can be enhanced through motivation. Motivation stems from Taylors' scientific management theory when in one of his four principles advocated for establishment of a rewarding system for goal achieving. According to Manu, Taylor's reward system is motivation [20]. Basing on this definition, the leader has to influence the workers by motivating them in order to perform [20]. Motivation serves as a factor which pushes the workers to strive to achieve their objectives and goals.

Staff development is another way of promoting good performance since it has been observed that there is a gap in leadership training to prepare head teachers for this role [21]. According to Manu \& Okumbe the "enlightened manager will recognize and support workers" needs at the highest level by providing opportunities for advancement, encouraging personal development, and creating an environment where employees can explore their individual talents and dreams" [20].

Further, the head teacher should ensure that new staff are properly oriented into the school system and general way of doing things. This is another aspect of making the new employee accepted in the institution [21].

Instructional performance includes the availability of teaching-learning materials and their coordination for proper use. They include: textbooks and visual aids [22]. The availability of textbooks and other instructional materials have a positive correlation on students; performance because they facilitate understanding of abstract concepts, helps in class control and others [23]. The researchers concur but add that it is not utilization alone rather teachers "commitment to professionalism; schemes of work, lesson planning, creative mind and interest in students" learning and performance, by having in mind what they want their students to achieve at the end of an education cycle that will propel teachers to make use of teaching aids.

According to Penny, Ward, and Bines, secondary schools in Uganda consider textbooks essential for performance but few students have the reading skills and capacity to research and access information. In the view of the researchers, if the teacher is managed well: motivated and developed can impart into the learners and inculcate into them the reading culture [6]. This is where the researchers agree and argue that students need to cultivate reading culture by developing personal initiative driven by goal orientation, what one wants to be after school that makes them read and perform.

However, Manu and Okumbe advocates for the recent method of supervision known as clinical supervision. This is when the head teacher diagnoses the source of the problem together with the teacher, say during classroom supervision. When the problem is found beyond the teacher, action research can be done to establish the problem and its solution [20].

In such a case the supervisor will be evaluating or auditing the educational teaching-learning process [24].

According to Manu and Okumbe for a head teacher to be effective in supervision has to have basic skills in supervision: Conceptual Skills. These involve the ability to acquire, analyze and interpret information in a logical manner [20].

Not much has been written on school discipline and yet it is an important component of school performance, hence, a need for wider research on it. Nevertheless, some authors have endeavored to relate discipline with performance as below:

Cascio, says that educational managers should be able to apply progressive disciplinary actions that are action proceeds from an oral warning, to written warning, to suspension and finally dismissal. This gives an employee opportunity for self-correction before more serious penalties [25]. In a related development, [20] agrees with [25] about the progressive discipline but he goes further to say that there should be principles of setting good disciplinary actions such as availing prior knowledge of rules and regulations. According to Manu \& Okumbe, disciplinary action should be given immediately, as this helps the offender to see close connection between desirable behaviour and its consequence [20].

\subsection{Challenges Faced by USE Head Teachers in School Curriculum Implementation}

The concept of an educational supervisor was first introduced in 1987, but the role has changed in recent years. [26], highlights the fact that supervision is a term that lends itself to different interpretations; thus, it does not necessarily mean someone looking over your shoulder all the time.

According to Alzaidi, the context surrounding the headship position has a number of features, such as a flat managerial structure and a centralized educational system [27]. This has an effect on how they deal with the challenges they encounter in their day-to-day work since they are equipped with teaching skills not administrative skills [4].

In a similar way, Leithwood, Day, Sammons, Harris, \& Hopkins put forward four strong claims about what constitutes successful head teachers' administrative skills, these included; (1) focusing on teaching pupils (2), responding to situations,(3) improving learning and develop leadership capacities and (4) distributing tasks between staff [28]. Relating to these, the quality and standard of administrative skills and the tasks as well as responsibilities of head teachers in Saudi Arabia below the expected level [29].

The challenges facing school head teachers may be derived from both internal and external sources [30]. One of these challenges is presented by the school building, and there is little doubt that the quality of a school building can determine the quality of the school's environment. He asserts that if the school building is of a high standard there will be an increased probability of a high standard of teaching and learning. [31], says that the physical environment can be considered as the second teacher.

In order for a successful head teacher to be able to establish a strong relationship with his or her students there need to be four prime core characteristics [32]. These are recognizing pupils' rights, having professional and high quality leadership, concentrating on pupil teaching, and having a focus on creating a learning organization. In fact, it is essential that a teacher feels confident in the head teacher's ability, respects her abilities, and has an appreciation for her 
achievements [33].

In a study carried out by LINS, it was found out that head teachers in most of the countries were challenged by poor time keeping. Poor time keeping among teachers is a major problem in some countries. Teachers arriving late, finishing early, and leaving their classes during the day can seriously reduce total instructional time. In Uganda this amounted to only 13 hours per work, Ghana, it amounted to only 11 hours per week in 1997 [34], and an average of 17 hours per week in secondary schools in Tanzania.

Another challenge that has faced head teachers in trying to express their administrative skills is understaffing that results into teaching loads of teachers [35]. Due to introduction of Universal Secondary Education in 2008, class sizes have grown big for instance, in some schools between 60 and 75 . The Ministry of Education has to find a way of contenting with issues of large classroom against few teachers coupled with high rate of teachers' attrition rates [36]. Otunga, et al, agrees that there is indeed lack of enough teachers to handle the various subjects [37]. Increasing hours of work, larger class sizes, more subjects, and constantly changing curricula are cited as major barriers to meeting the curriculum in many countries. In Uganda, most USE schools had shortfalls in some subjects especially humanities, Sciences studies leading to poor syllabus coverage. Other teachers were forced to teach subjects they never trained in [22].

What is expected from teachers (the 'social contract') is not pitched at a realistic level in many countries with USE programme given material rewards, workloads, and work and living environments. In many countries, teachers are being asked to take on more responsibilities, including HIV/AIDS education, counseling, and community development [38]. The ministries guideline on the number of lessons to be taught to be 27 lesson added salt into the injury. An average teacher has 6 lesson out of the 9. This is a problem to especially the languages and mathematics teachers who require to mark students' books daily. This affects the learning and teaching process and in the long run head teachers administrative skills are limited [39].

Furthermore, students, Teacher absenteeism and late coming is another challenge that usually faces head teachers. Failure to meet the curriculum and lack of accountability is widely reported to result in high levels of teacher absenteeism. High levels of teacher absence were reported in two African countries-Kenya 28.4 per cent and Uganda 27.0 per cent [40]. However, it is also difficult to measure teacher absenteeism that can be directly attributed to poor motivation and opportunistic behavior.

\subsection{Study Recommendations to the Above Challenges}

The relationship between head teachers and teachers will be considered successful if it is based on fair treatment and mutual trust [26]. Yet, if there is a lack of justice, then this may lead to a weakness in confidence concerning the head teacher. In fact, it is essential that a teacher feels confident in the head teacher's ability, respects her abilities, and has an appreciation for her achievements [33].
Supervision is a term that lends itself to different interpretations; thus, it does not necessarily mean someone looking over your shoulder all the time [26]. At the same time, the head teacher will encounter challenges in working with an educational supervisor, such as a lack of coordination and support between the two. Head teachers need people to listen to them, be shown concern for their well-being, and to be given affirmation and encouragement [43].

Schools can be considered as social institutions, which are created to serve the community and educate children therefore, there should be a close link between the school and the local community.

In addition, Bernstein notes that it is obvious that classification and framing are important in this paper and could be utilized as conceptual framework because it examines the power relations that operate between head teachers, supervisors and teachers [41].

In Uganda, the government recognized that education was a vehicle for national development and set up a commission that found that there was a need for a systematic identification of the needs of teachers so that the welfare practices programmes could be organized systematically [42]. The Commission also recommended large scale expansion of post primary schools. Institutions which have ignored these practices have recorded minimum productivity [44].

\subsection{Relationships Between Head Teachers Administrative Skills and Curriculum Management in USE Schools}

Formal institutions including secondary schools are established to impart knowledge, skills, habits, values and attitudes among the learners. According to [45] and [46], curriculum is defined as the quality and quantity of knowledge, skill, techniques, positive attitude behavior and philosophy that students acquire. The ability to manage curriculum is evaluated by marks and grades obtained in a test or examination, at the end of a topic, term, year or education cycle. The authors further assert that the quality of grades and number of candidates who pass in the various grades determine the level of academic performance of a given class or institution in a given period of particular examination whether internal or public hence curriculum management determines students' performance. The available records from Uganda National Examinations Board (UNEB) and school files indicate poor performance of secondary schools at both Uganda Certificate of Education (UCE) and in Uganda Advanced Certificate of Education (UACE) in Kiruhura district, as compared to national performance.

\subsubsection{Head Teachers' Influence on Academic Performance}

Many scholars assert that among other factors that enhance learners' good academic performance in schools is the administrative skills exerted by head teachers, teachers and parents are major contributing factor [47]. The author adds that the head teacher is the custodian of education standard. The authors however, do not indicate how head teachers can acquire the required leadership and management skills, which can sufficiently be acquired through training [17]. It should 
be noted that the majority of head teacher have skills to teach, not to lead or manage schools, but they are promoted to leadership some of them without going through induction course at least. There is increasing poor performance in secondary schools mainly in science subjects which poor performance she attributed to poor leadership at the school level [22]. In the same vein, [43] contends that most schools are failing to manage the curriculum due to the gap in leadership and management skills. He continued to say that strikes are common because of poor head teachers' administrative skills towards solving problems.

\subsubsection{Managerial Role and Curriculum Management}

For curriculum management to be set up in a school the leader must take up the administrative skills. Further, administrative skills include decision making, direction, coordination, supervision, evaluation and budgeting [48]. There must be comprehensive management plan or content which schedules for implementation. Resource allocation and criteria and procedure for ongoing evaluation. This includes contents like operational school philosophy from social cultural and educational values of the nation, description of the general school characteristics for example. Special features, facilities, equipment and staffing; pupil characteristics, admission requirements, school year planner including programs, departmental concerns and the like, school goals derived from operational school philosophy or community.

\subsubsection{Factors That Determine Successful Curriculum Management}

In the literature reviewed, the researchers discovered that many scholars researched on poor academic performance in secondary schools from a number of angles, such as availability of quality teachers, availability of instructional materials, school resources and facilities, leadership styles of head teachers and nature of family background but the angle of administrative skills of the school head teachers' is not handled, which the researcher is interested in.

In Uganda, Nsubuga, carried a research on the topic, "Analysis of leadership styles and school performance of secondary schools in Uganda". The study revealed that leadership styles influenced school performance by 0.615 or $61.5 \%$. Nevertheless on the other hand, leadership contributed 0.328 or 32.8 to students ${ }^{\text {ee }}$ academic performance, leaving $67.2 \%$ for extraneous variables like quality of teachers, availability of school facilities, and resources, instructional materials, the experience of head teachers and the school culture [19]. Among the extraneous variables identified by the study that affect good academic performance, head teachers' administrative skills and curriculum management in USE schools was missing and yet it is likely to affect the students' performance, hence a need to investigate on it.

Drajo, carried out research regarding operational management and its effect on the academic performance of secondary school students in Adjumani district. The study focused on management of school finances, facilities and human resource in general. The results show that there is a significant relationship between operational management and academic performance. The study however, does not consider how these operation management knowledge and skills are acquired which calls for research on the acquisition of the same [49].

In a related development, Mpierwe conducted a study to examine the effect of management of instructional materials on teachers' performance. Findings showed that there was a positive relationship between instructional materials and teachers' performance [50]. Similarly, Masebo investigated whether non- academic factors such as family background, economic status, health of students affect the schools' curriculum management. It was proven that social-economic factors affect the schools' curriculum management [51].

\subsubsection{Head Teachers' Experiences and the School Performance}

Administrative skills means familiarity with a skill or a field of knowledge acquired over months, or years of actual practice and which presumably has resulted in superior understanding or mastery [45].

For instance, in Uganda for one to apply as for the position of deputy headmaster, he/she must have an experience of eight years of teaching and must have been a caretaker deputy head teacher "O" level day secondary school for at least five years.; whereas, one to qualify for an Advanced level ("A" level) head teacher, must have a minimum teaching experience of twelve years. They must also have at least three years' experience of administration, as a substantive head teacher Ordinary level day school.

\section{Methodology}

\subsection{Study Design}

A cross sectional study design was used for this study. This design was appropriate for this research because it entailed the collection of data more than one case at a single point in time, in order to collect a body of quantifiable data in connection with how head teachers' administrative skills and curriculum management in universal secondary education schools were correlating. One of the best known advantages of a cross sectional study is that it provides the researcher with a consistent benchmark in terms of objectivity, reliability and validity [52] hence the reason why was preferred for this study.

The study was based on case study of Kiruhura District because it portrayed accurately the characteristics of a situation in other secondary schools under USE in the districts of Uganda in terms of structures, regulation, recruitment and development, criteria bias was reduced and reliability of evidence collected was maximized. Amin, supports the use of case studies especially where the area had not been studied before [53].

\subsection{Study Population}

The study focused at all the head teachers in all the USE schools in Kiruhura district. Head teachers are always instructed by the District Education Officer (DEO) hence the DEO and his staff was considered and acted as key informants 
for this study.

\subsection{Sample Size Determination}

The study relied on Yamane (1967) formula to determine the sample size from the targeted population as shown below

$$
\mathrm{n}=\frac{N}{1+N(\mathrm{e})^{2}}
$$

Where $\mathrm{N}=$ Number of the total population

$\mathrm{n}=$ sample size

$e^{2}=0.05$ level of significance

Therefore, the sample size of respondents from universal secondary education schools in Kiruhura district was

$$
\frac{30}{1+30(0.05)^{2}}
$$

$\mathrm{n}=23$ Respondents

\subsection{Sampling Strategy}

\section{(i) Simple Random Sampling}

In this study, non-probability sampling techniques were used to select the respondents. In this case snow ball sampling was used to select the head teachers under USE schools in Kiruhura to participate in the study. The sampling method was preferred because it offered respondents equal chances of participating in the study and at the same time, the investigator was able to easily identify the Head teachers in the schools under USE. The researcher went to the first head teacher who later directed her to the other head teacher and the circle continued until the targeted sample size was met.

\section{(ii) Purposive Sampling}

Respondents from the DEO's office were key informants for this study and were sampled using purposive sampling.

\subsection{Sources of Data}

Mainly, there are two sources of data namely primary data and secondary data.

\subsubsection{Primary Data}

Primary data was attained from selected respondents by use of self-administered questionnaires to head teachers. The administered questionnaires helped to avoid excuses forgetting to fill the questionnaires as the researcher administered the questionnaires herself.

\subsubsection{Secondary Data}

Secondary data was collected from articles, internet, journals and other documentary evidences that were found related to the phenomena under investigation.

\subsection{Research Instruments}

The following research instruments were used to collect data:

\subsubsection{Questionnaire}

The questionnaires were structured following the pertinent study objectives and thus, they had sections with headings that reflected the study objectives. Questionnaires with both closed and open ended questions were self-administered to the respondents since all of them had the ability to read and write.

\subsubsection{An Interview Guide}

The interview guide with open ended questions was also used by the researchers to collect information from the study key informants that were, the respondents from the District Education Office of Kiruhura District.

\subsection{Validity and Reliability of Research Instruments}

\subsubsection{Validity}

This process of validation involved collecting and analyzing data to assess the accuracy of an instrument. As a measure to assess the validity of quantitative instruments, the process involved generally pilot testing with a main focus on external and content Validity.

\section{(i) External Validity}

The main intent of this validity was established to the extent to which the results of this study could be generalized from a sample to a population. Some respondents were selected out from which Questionnaires and Interview guides were pretested. These respondents used in the pre testing of research instruments were not used in the final data collection.

\section{(ii) Content Validity}

This was intended to establish the appropriateness of the content of a research instrument. The research instruments were tested out with some respondents and the outcomes were evaluated against the desired outcomes. Then the researchers ensured that a panel of expert judges like supervisors and other research experts had to evaluate the instruments to assess their validity [54].

\subsubsection{Reliability}

To measure reliability of the research instruments, the Test-Retest reliability method was used and this included administering items that measure a certain concept to a set of respondents now and again to the same respondents and then comparing the results of the scores obtained at the two different times from one and the same set of respondents, [54]. According to [53], test re-test reliability can be used to measure the extent to which the instrument will give consistent scores when the same group of individuals repeatedly measure on the same conditions. Thereafter the results from the pre-test were used to modify the items in the instruments.

\subsection{Data Processing, Presentation and Analysis}

Upon collecting data several methods were used to process and analyze the data. The analysis of data required a number of closely related operations such as establishment of categories, application of these categories to raw data through editing, coding and tabulation and finally drawing of statistical inferences [55]. The researchers classified the raw data into same purposeful and usable categories. Editing was done to improve the quality of the data for coding, coding operations was done at this stage through which the categories 
of data was transformed into symbols that was tabulated and counted, tabulation in this case, and the classified data was mechanically put in form of tables.

\subsection{Ethical Consideration}

The researchers sought approval from Mbarara University of Science and Technology Research Ethics committee (MUST-REC). At the district level, permission to conduct the study was obtained from the local leaders and Chief Administrative Officer before conducting the study. The free and informed consent of each individual participant was obtained at the start of the study.

\section{Data Presentation, Analysis and Interpretation}

\subsection{Head Teachers Administrative Skills in Managing Curriculum in Universal Secondary Education (USE) Schools in Kiruhura District}

\subsubsection{Status of the Schools}

Table 1. Status of the schools.

\begin{tabular}{lll}
\hline Response & F & \% \\
\hline Mixed day & 2 & 10 \\
Mixed day and Boarding & 18 & 90 \\
Total & 20 & 100.0 \\
\hline
\end{tabular}

Source: field data, 2016

The above table indicates the responses about the status of schools under USE as $18(90 \%)$ of respondents indicated mixed day and boarding schools than $2(10 \%)$ of the respondents that indicated mixed day schools. The reason for this percentage was Kiruhura district being in rural areas possessed different categories of students of whom some could not afford fees for boarding hence were day scholars.

\subsubsection{Funder of the School Curriculum Activities (Academic)}

Table 2. Funder of the school curriculum activities (academic).

\begin{tabular}{lll}
\hline Response & Frequency & Valid percentage \\
\hline MOE \& S & 16 & 80 \\
Parents & 0 & 0 \\
Both & 4 & 20 \\
Total & 20 & 100 \\
\hline
\end{tabular}

Source: field data, 2016

From the table above basing on the study findings, schools totaling to $80 \%$ that were the majority indicated that MOE \& S was the biggest funder of the school curriculum activities (academic) whereas the remaining small percentage of respondents of $20 \%$ indicated that both the MOE\&S were the Funders of the school curriculum activities (academic). This implies that the Funder of the school curriculum activities (academic) in secondary schools under USE was the MOE \& Sports.

\subsubsection{Funder of the School Curriculum Activities (Non-academic)}

Table 3. Funder of the school curriculum activities (non-academic).

\begin{tabular}{lll}
\hline Response & F & \% \\
\hline MOE \& S & 11 & 55 \\
Parents & 2 & 10 \\
Both & 7 & 35 \\
Total & 20 & 100 \\
\hline
\end{tabular}

Source: field data, 2016

Table above indicates responses derived from the studied schools concerning the Funder of the school curriculum activities (non-academic) as 55\% of the majority schools indicated MOE \& $\mathrm{S}$ as the biggest funder of school curriculum activities (non-academic), followed by $35 \%$ of the schools indicating both MOE\&S and Parents as funders of the school curriculum activities (non-academic) and finally the least percentage of respondents of $10 \%$ indicated parents as the funder of school curriculum activities (non-academic). Such findings therefore implies that the Funder of the school curriculum activities (non-academic) in schools under USE was the Ministry of Education and Sports. This was attributed to the fact that the targeted schools were already government aided hence the reason for the biggest percentage of respondents

\subsubsection{Methods Used by the School Heads to Manage Both Academic and Non-academic staff in Handling Curriculum Activities}

Table 4. Methods used by the school heads.

\begin{tabular}{lll}
\hline Response & F & \% \\
\hline Supervising every activity & 9 & 17.6 \\
Instructing heads of sections to manage their departments & 5 & 9.8 \\
Reading and reacting to reports & 6 & 11.8 \\
Reacting to the comments of the public and community around & 2 & 3.9 \\
Filling gaps and answering quarries spot on & 2 & 3.9 \\
Managing the prevailing crisis & 3 & 5.9 \\
Delegating Management by walking around (MBWA) & 7 & 13.7 \\
Soliciting the intervention of higher authorities & 2 & 3.9 \\
Meetings and minute follow up & 8 & 15.8 \\
Personal decision as man on the spot & 7 & 13.7 \\
Total & 51 & 100 \\
\hline
\end{tabular}

Source: field data, 2016

Basing on the field study findings, the table above indicates the findings in response to the Methods used by the school heads leading to both academic and non-academic staff to handle curriculum activities as $17.6 \%$ of the respondents that were the majority indicated supervising every activity, followed by $15.8 \%$ of the respondents that indicated meetings and minute follow up in the secondary schools, $13.7 \%$ of the respondents indicated Personal decision as man on the spot that shared the same percentage of respondents with delegating management by walking around followed by $11.8 \%$ of respondents that indicated reading and reacting to reports as the Methods used by the school heads leading to both academic and nonacademic staff to handle curriculum activities. On the other hand $3.9 \%$ of 
the study respondents indicated soliciting the intervention of higher authorities that shared the same percentage with Filling gaps and answering quarries spot on and reacting to the comments of the public and community around. From the above findings therefore, it can be seen that supervising every activity in the school was the most method used by the school heads leading to both academic and non-academic staff to handle curriculum activities.

\subsubsection{Assessment Tools Often Used in Assessment in the Schools}

Table 5. Assessment tools often used in assessment in the schools.

\begin{tabular}{lll}
\hline Tool & F & \% \\
\hline Beginning of term Exams (BOT) & 12 & 37.5 \\
Mid-term Exams (MT) & 10 & 31.3 \\
Weekly tests & 3 & 9.4 \\
Monthly tests & 2 & 6.2 \\
Surprise tests & 5 & 15.6 \\
Total & 32 & 100 \\
\hline
\end{tabular}

Source: field data, 2016

The table above presents the finding that were derived from the study respondents in response to the Assessment tools often used in the schools as $37.5 \%$ of the respondents that were the majority indicated beginning of Term Exams (BOT), followed by $31.3 \%$ of the respondents that indicated Mid-term Exams (MT) whereas the least percentage of respondents was $6.2 \%$ respondents identifying monthly tests as the assessment tools often used in assessment in the schools. This therefore implies that most of the secondary schools under USE in Kiruhura district were using Beginning of term Exams (BOT) as the assessment tools often used in assessment in the schools hence was represented by the majority of the respondents. Other assessment tools identified included surprise tests with $15.6 \%$ respondents and weekly tests with $9.4 \%$ respondents.

\subsubsection{How Irregularity of Students' and Examination/Tests Attendance Is Handled}

Table 6. How irregularity of students' and examination/tests attendance is handled.

\begin{tabular}{lll}
\hline Response & F & $\mathbf{\%}$ \\
\hline Instant punishment & 16 & 37.2 \\
Handled by the academic board & 3 & 7.0 \\
Handled by the school disciplinary committee & 5 & 11.6 \\
Parents called & 3 & 7.0 \\
Suspension/expulsion without caution & 2 & 4.6 \\
Suspension/expulsion after caution & 14 & 32.6 \\
Total & 43 & 100 \\
\hline
\end{tabular}

Source: field data, 2016

In response to how irregularity of students' and examination/tests attendance is handled, table above presents the findings from the study respondents as $37.2 \%$ of the respondents that were the majority indicated Instant punishment compared to the minority of the respondents that identified Suspension/expulsion without caution with $4.6 \%$ responses. Other responses included Suspension/expulsion after caution with $32.6 \%$ of respondents, Handled by the school disciplinary committee with $11.6 \%$ respondents and finally, $7 \%$ of the respondents that identified Handled by the academic board and Parents called. From the above findings therefore, it can be identified that instant punishments was the most way on how irregularity of students' and examination/tests attendance was handled hence the reason for the highest percentage of respondents.

\subsection{Challenges and Suggested Solutions for Proper Management of the School Curriculum}

\subsubsection{Challenges Encountered in Administering the Academic Curriculum}

Table 7. Challenges encountered in administering the academic curriculum.

\begin{tabular}{lll}
\hline Challenge & F & $\mathbf{\%}$ \\
\hline Absenteeism by both students and teachers & 19 & 26.8 \\
Strikes as a result of indiscipline & 17 & 23.9 \\
Understaffing & 10 & 14.1 \\
Inadequate resources & 10 & 14.1 \\
Delay of USE funds & 9 & 12.7 \\
Wide curriculum & 6 & 8.4 \\
Total & 71 & 100 \\
\hline
\end{tabular}

Source: field data, 2016

The table above, basing on the study field, presents findings in response to the Challenges encountered in administering the academic curriculum as $26.8 \%$ of the study respondents that were the majority identified absenteeism by both students and teachers as the most challenge in comparison to the minority percentage of respondents of $8.4 \%$ that identified wide curriculum. Other challenges encountered in administering the academic curriculum that were indicated by the study respondents included strikes as a result of indiscipline with $23.9 \%$, followed by understaffing that shared the same percentage of $14.1 \%$ with Inadequate resources and finally $12.7 \%$ of the respondents identified delay of USE funds.

From the findings therefore, absenteeism by both students and teachers was identified as the most Challenge encountered in administering the academic curriculum hence they possessed the highest percentage of study respondents.

\subsubsection{Solutions to the Challenges Faced by Secondary School Head Teachers in School Curriculum Management in USE Schools}

Table 8. Solutions to the challenges faced by secondary school head teachers.

\begin{tabular}{lll}
\hline Challenge & F & \% \\
\hline Parents intervention & 8 & 15.4 \\
Government recruitment of enough staff & 13 & 25 \\
Government equipping schools with enough resources & 9 & 17.3 \\
Available teachers need motivation & 7 & 13.5 \\
Government releasing funds in advance & 15 & 28.8 \\
Total & 52 & 100 \\
\hline
\end{tabular}

Source: field data, 2016

In response to the challenges suggested by the respondents to the challenges encountered in administering the academic curriculum, table above presents respondent's responses as $28.8 \%$ 
of the respondents that were the majority identified government releasing funds in advance in comparison with $7 \%$ of the respondents that were the minority of the respondents that identified available teachers need motivation. Other suggested possible solutions to the challenges encountered in administering the academic curriculum included $25 \%$ respondents identifying government recruitment of enough staff, government equipping schools with enough resources with $17.3 \%$ and Parents intervention with $15.4 \%$ of the respondents.

From the findings above therefore, it can be identified that government releasing funds in advance in the possible solution to the challenges faced by secondary school head teachers in attempt to manage school curriculum in USE schools hence the reason for such percentage.

\subsection{Relationship between Head Teachers' Administrative Skills and Curriculum Management in USE Schools in Kiruhura District}

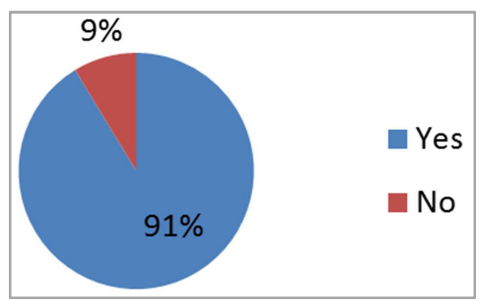

Source: field data, 2016

Figure 1. Relationship.

In regard to the relationship between Head teachers' administrative skills and curriculum management in USE schools in Kiruhura district, $91 \%$ of respondents that were the majority indicated yes whereas only $9 \%$ of the respondents that were the minority indicated No.

This therefore implies that there was a relationship between Head teachers' administrative skills and curriculum management in USE schools in Kiruhura District as represented by the highest percentage of respondents of $91 \%$.

\section{Discussion of Findings}

\subsection{Head Teachers' Administrative Skills in Managing Curriculum in Universal Secondary Education (USE) Schools}

Respondents were required to indicate their responses on the methods used by the school heads leading to both academic and non-academic staff to handle curriculum activities, $17.6 \%$ of the respondents that were the majority indicated supervising every activity taking place in the school whether academic or non-academic was the head teachers administrative skills in managing curriculum in secondary schools. According to [20] supervision of teachers assists them to be effective in classroom teaching and advises that clinical supervision in which the head teacher diagnoses the source of the problem together with the teacher, say during classroom supervision would be the best option. On the assessment tools often used in assessment in the schools, Beginning of Term Exams (BOT) was the most assessment tool that was often used in the USE schools as represented by $37.5 \%$ of the respondents. Therefore, respondents indicated that this was the most head teacher's administrative skill in managing curriculum in universal secondary education (USE) schools in Kiruhura District. In the same way [21] indicates that there assessment tools are always key to success by managers in running organizations and need to be adopted highly.

Further, respondents were required to express their opinions in response to how irregularity of students' and examination/tests attendance is handled; instant punishment was the highly suggested way as represented by the majority of the respondents of $37.2 \%$. According to the respondents, instant punishment through suspension, caning, cleaning the compound and re-doing the tests were helping in curbing up the discipline and academic of the students and was an administrative skill that was used by head teachers of USE secondary schools. [6], argues that students need to cultivate reading culture by developing personal initiative driven by goal orientation, what one wants to be after school that makes them read and perform and this depends on the head teachers guidance.

\subsection{Challenges and Suggested Solutions for Proper Management of the School Curriculum}

Absenteeism by both students and teachers was the most challenge encountered by head teachers in administering the academic curriculum as represented by the majority of respondents of $26.8 \%$. Such respondents had their arguments such as there were many issues that caused absenteeism such as delay of the government to release the salaries on the teacher's side in addition to few teachers that were pertaining in different secondary schools that caused absenteeism. On the other hand, students were also influenced by their parents not to attend school regularly as they were farmers in Kiruhura while at the same time some students were in peer groups that influenced them to be in activities like alcohol, drug abuse that all limited them from attending school.

As a possible solution to the challenges faced by secondary school head teachers in attempt to manage school curriculum in USE schools, government releasing funds in advance was the most possible solution suggested by the study respondents as represented by $28.8 \%$. Such respondents indicated that as a way of motivation, there is the need for the government to always release salaries in time so that the teachers' absenteeism is controlled. They further indicated that the teachers can influence this by writing the reports in advance so that the payrolls could be updated. Also, on the students side, respondents had their concerns that the head teachers have the mandate to put students and parents on pressure that the school fees is paid in time to minimize absenteeism hence managing the curriculum in USE Secondary schools. This is related to [56] from the NCSL (National College for School Leadership) focused on a link between the head teacher and culture; they found that successful head teachers create and model their 
schools' culture to one that suits them, in order to make improvements and changes.

\subsection{Relationship Between Head Teachers'Administrative Skills and Curriculum Management}

For this objective, majority indicated "Yes" response, an indicator that there was a relationship. Such respondents had their arguments that it is the head teacher that determines the performance of the school through motivation skills of the teachers and students. This is similar to [47] who suggested that among other factors that enhance learners' good academic performance in schools is the administrative skills exerted by head teachers.

\section{Summary of Findings}

\subsection{Head Teachers' Administrative Skills in Managing Curriculum in Universal Secondary Education (USE) Schools}

The head teacher's administrative skills in managing curriculum in universal secondary education (USE) schools in Kiruhura District was judged on head teachers involving both males and females as represented by the highest percentage of respondents of $90 \%$ and basing on the fact that majority of the schools being day mixed schools.

\subsection{Challenges and Suggested Solutions for Proper Management of the School Curriculum}

On the Challenges and suggested solutions faced by Secondary School Head teachers in their attempt to manage the school curriculum in USE schools in Kiruhura District, Absenteeism by both students and teachers was the most challenge encountered by head teachers whereas Government releasing funds in advance was the most possible solution suggested by the study respondents

\subsection{Relationship between Head Teachers' Administrative Skills and Curriculum}

There was a relationship between teachers' administrative skills and curriculum basing on majority of the study respondents indicating yes response.

\section{Conclusions}

\subsection{Head Teachers' Administrative Skills in Managing Curriculum}

The study concludes that involving all teachers in the curriculum activities is the most Head teachers' administrative skills in managing curriculum in USE schools in Kiruhura District

\subsection{Challenges and Suggested Solutions for Proper Management of the School Curriculum}

Absenteeism by both students and teachers was the most challenge encountered by head teachers whereas Government releasing funds in advance was the most possible solution suggested by the study respondents

\subsection{Head Teachers' Views about Administrative Skills and Curriculum Management}

Finally the study concludes that there was a relationship between Head teachers' administrative skills and curriculum

\section{Recommendations}

a) To establish monthly workshops aimed at improving head teachers administrative skills in order to attain an improved curriculum management in USE schools.

b) The study recommends that there is need for the government to increase the USE schools teachers' and head teachers' salaries so that they are motivated.

c) Students in USE schools should choose peer groups that are productive in terms of education career and moral uplift to attain good academic performance.

d) Parents should endeavor to provide all the school requirements such as uniforms, books so that they do not disorganize their children when the term is already underway.

\section{References}

[1] Naidoo, S. (2014). School leadership style important for curriculum reforms NIST/SEMATEK.

[2] Kirui, P. K. (2012). Institutional factors influencing head teachers' implementation of curriculum change in public primary schools in kipkelion district. Unpublished master's thesis, University of Nairobi, Nairobi Kenya.

[3] Hargreaves A. (1992) Understanding Teacher Development. London, Cassell/ New York, Teachers College Press.

[4] Alkarni, A, \& Brian C. (2014) Problems which may challenge the ability of secondary school head teachers in the city of Tabuk to lead their schools professionally, Arecls Vol. 11, 55-74.)

[5] Keating, J. (2001). Firm Demand for Post Primary Qualifications. Report to the Secondary Education Commission. World Bank, MoES, Kampala, Washington, DC.

[6] Penny, A., Ward, M., Read, T., Bines, H., (2008). Education sector reform: the Ugandan experience. International Journal of Educational Development 28 (3), 268-285.

[7] Kamakamu, W., W. (2007). Policy implementation: Stakeholder perspectives on the implementation of secondary education decentralization in Uganda, Kampala.

[8] Deaeghere, J., Williams, R. \& Kyeyune, R. (2008). Ugandan secondary school head teachers' efficacy: What kind of training for whom? International Journal of Educational Development, 29, 312-320.

[9] Mulkeen, A., Chapman, D. W., De Jaeghere, J., Leu, E. (2007). Recruiting, Retraining Retaining Secondary School Teachers and Head Teachers in Sub-Saharan Africa. World Bank Working Paper \#99. The World Bank, Washington, DC. 
[10] UNATU. (2015). The Uganda National Teachers Union Annual Report Vance September 8, 2011.

[11] Peter N. Waweru \& Orodho J. Aluko (2014) Management Practices and Students' Academic Performance in National Examinations in Public Secondary Schools in Kiambu County, Kenya. International Journal of Recent Scientific Research, 6, 1126-1133.

[12] Uganda National Examinations Board (UNEB) (2015). Examination Results. Kampala, Uganda.

[13] Taylor F. W., (1991) \& Zais (1976), "The Principles of Scientific Management" in J. M Shafritz \& J. S. Ott (Eds), (pp. 66-79). Belmon, C. A: Wadsworth Publishing Company.

[14] De Grauwe, A., (2001). School Supervision in Four African Countries. Vol. 1. Challenges and Reforms. IIEP, UNESCO, Paris.

[15] Anderson, J. B. (2005). Improving Latin America's school quality: which special interventions work? Comparative Education Review 49 (2), 205-229.

[16] Ministry of Education (2015). Strategic Plan 2010-2016. Nairobi: Government Printers.

[17] Balanskat, A. \& Gerhard, P. (2005) Head teacher Professional Profile and Roles across Europe, Corrigenda OECD, UK.

[18] Ministry of Education and Sports (2009) The Education and Sports Sector Annual performance Report (ESSAPR), covering the period $1^{\text {st }}$ July $2007-30^{\text {th }}$ June 2008. M\&E Section, Education Planning Department, Ministry of Education and Sports, the Republic of Uganda. Page 6.

[19] Nsubuga, Y. K. K (2009) Assessment of Leadership Styles and School Performance of Secondary Schools in Uganda, Unpublished Ph.D Dissertation, Makerere University Kampala.

[20] Manu J. A Okumbe (2007). Educational management: Theory and practice Nairobi: Nairobi University Press.

[21] Kyeyune, R. (2003), "The Changing Face of Leadership" Educational Leadership 59, 8; 61-63.

[22] Bitamazire, N. G. (2005). Status of Education for Rural People in Uganda. Paper Presented at the Ministerial seminar on education for rural people in Africa. Addis Ababa, Ethiopia.

[23] Ajuago, M. A. (2003). Impact of Instructional Materials on Academic Performance of Selected Primary Schools in Kisumu District. Unpublished Dissertation Makerere University, Kampala.

[24] Fapojuwo, J. O. (2002) "Effective Leadership and supervision." A paper Presented at the Programme on Management of Human Resources organized by NCEMA.

[25] Cascio W. F (1999) Applied Psychology in Human Resource Management, $5^{\text {th }}$ Edition, New Jersey, Prentice Hall.

[26] Cooper, N. \& Forrest, K. (2009). Essential Guide to Educational Supervision in the Foundation Programme. Chichester: Wily-Blackwell.

[27] Alzaidi, A. (2008). A study of Job Satisfaction among Male Secondary School Head Teachers in Saudi Arabia. PhD Thesis. Newcastle University.

[28] Leithwood, K., Day, C., Sammons, P., Harris, A., \&Hopkins, D.
(2006). Seven strong claims about successful school leadership. Nottingham, UK: National College of School Leadership.

[29] Alsharari, J. (2010). The perceived training needs of female head teachers compared with the training needs of male head teachers in the government public schools in Saudi Arabia. Durham University.

[30] Jirasinghe, D. and Lyons, G. (1996) The Competent Head: A Job Analysis of Heads' Tasks and Personality Factors, The Falmer Press, London.

[31] Sanoff, H. (2001), "School Building Assessment Methods", NCEF, Washington, D. C.

[32] McGilchrist, B., Myers, K. and Reed, J. (2004). The intelligent school ( $2^{\text {nd }}$ Edition $)$. London: Sage.

[33] Crawford, M. (2014). Developing as an Educational Leader and Manager. London, SAGE.

[34] LINS. (1999). Teacher conditions of service in developing countries. Centre for Literature, 1.

[35] Odhiambo G. (2005) "Teacher appraisal: the experiences of Kenyan secondary school teachers", Journal of Educational Administration, 4, 402 - 416 .

[36] Ingersol, R. M. (2001). Teacher Turnover and Teacher Shortages: An Organizational Analysis. American Education Research Journal, 499-534.

[37] Otunga, R., D. Serem, D. K. \& J. Kindiki. (2008). School Leadership Development in Preparation and Development of School Leaders. New York. Routledge.

[38] Bennell, P. (2004). Teacher Motivation and Incentives in Sub-Saharan Africa and Asia. Knowledge and Skills for Development, Brighton.

[39] Chemisto, M. E. (2007). Challenges facing head teachers in the management of the Teaching personnel. A study of public secondary schools Mt. Elgon district, Kenya. Unpublished Masters report of Kenyatta University.

[40] Glewwe, P., N. Ilias \& M. Kremer. (2003). Teacher incentives. Mimeo. Global Campaign for Education. 2004. GCE response to World Development Report 2004 outline. Mimeo.

[41] Bernstein (2000) cited in Cause, L. (2010). Bernstein's Code Theory and the Educational Researcher. Asian Social Science, $6(5), 3-9$.

[42] Opolot C. O, Mary G. N, \& Connie M. S (2006) School administrators' views on handling large classes in primary schools in Uganda: Implications for Teacher education. Journal of International Cooperation in Education.

[43] Boerema, A. L. (2011). Challenging and Supporting New Leader Development. Educational Management Administration \& Leadership, 39 (5), 554-567.

[44] Mullins, L. J. (2002). Management and Organizational Behaviour. (6 ${ }^{\text {th }}$ Edition). Harlow: Prentice Hall.

[45] Odubuke, R P. E. (2007), Head teachers' Training Programme and their Competences in the Management of the Primary Schools in the North-western Uganda. A Ph.D Dissertation in Education Administration, Planning and management, Makerere University, Kampala. 
[46] Kaggwa, V. (2003) Contribution of teachers' involvement in school administration on students' academic performance in private secondary schools. Kampala: Makerere.

[47] Nambuba - Namusoke J. (2005), the Influence of Head teachers Work Plan on the Academic Performance of Pupils in selected. Schools in Mbale District, Unpublished Dissertation, Makerere University Kampala.

[48] Musaazi J. C. S. (2006), Educational Planning; Principles, Tools and Applications in the Developing World Makerere University Kampala - Uganda.

[49] Drajo (2010), Operational management and its effect on the academic performance of secondary school students in Adjuman district Uganda. Unpublished thesis.

[50] Mpierwe (2007). The effect of management of instructional materials on teachers' performance in Kampala district. Kampala-Uganda.
[51] Masebo, H. J. (2008), Marketing Research 4th ed. McGraw Hill. Data Analysis: Testing for Association ISBN 0-07-340470-5.

[52] Kumekpor, T. K. B. (2002) Research methods and techniques of social research. Accra: SonLife Press \& Service: 137-138.

[53] Amin. M. E. (2005), Social Science Research, Conception, Methodology and Analysis. Printed and Published in Uganda by Makerere University Printery, Kampala, Uganda.

[54] Sekaran, U. (2003) Research Methods for Business: A skill Building Approach, $4^{\text {th }}$ Edition, London: John Wiley \& Sons.

[55] Kothari, C. R, (2004), Research Methodology Methods and Techniques New Age International (P) Limited, Publishers New Delhi.

[56] Lewis P. \& Murphy R. (2008) A review of what is known about effective leadership and leadership development Centre for Developing and Evaluating Lifelong Learning, School of Education, University of Nottingham. 